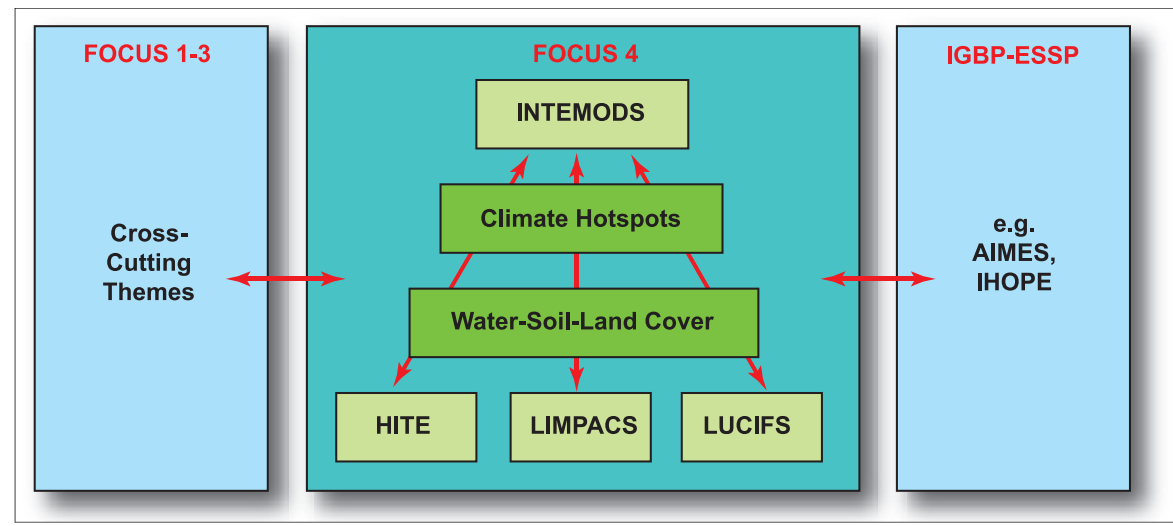

Figure 3: PHAROS Focus 4 structure, links and interactions showing four Activities (INTEMODS, HITE, LIMPACS, LUCIFS), short-term regional-global priorities (Climate Hotspots, Water, Soil and Land Cover), and links to PAGES Cross-Cutting Themes and other IGBP-ESSP programs/projects.

\section{Activity 2: HITE - Human-Climate Interactions with the Terrestrial Environment.}

The HITE Activity is designed to further the study of paleorecords and other ecological archives in documenting and understanding the interactions between human activities and terrestrial ecosystems through time, thereby ensuring the security and services of terrestrial ecosystems for the future. Three working groups cover: New Case-Studies, Regional Syntheses and Land Cover Syntheses (linking closely with POLLANCAL).
Activity 4: LUCIFS - Land Use and Climate Interactions with Fluvial Systems

LUCIFS focuses on a systems-based understanding and analysis of the relationship between the external drivers of land use and climate change on fluvial/sediment processes over timescales that encompass the period of agriculture. Working groups include: Regional and Global Syntheses of Case Studies; Advanced Case Studies; Modeling; and Linking Rivers to the Coast.

\section{References:}

Battarbee, R.W., Monteith. D. Juggins, S. Evans, C. D, Jenkins, A and Simpson, G.L., 2005: Reconstructing pre-acidification pH for an acidified Scottish loch: a comparison of palaeolimnological and modelling approaches, Environmental Pollution, 137: 135-149.

Dearing, J.A., 2006: Climate-human-environment interactions: resolving our past, Climate of the Past, 2: 187-203.

Dearing, J.A., Battarbee, R.W., Dikau, R., Larocque, I. and Oldfield, F., 2006a: Human-environment interactions: towards synthesis and simulation, Regional Environmental Change, 6: 1-16.

Dearing, J.A., Battarbee, R.W., Dikau, R., Larocque, I. and Oldfield, F., 2006b: Human-environment interactions: learning from the past, Regional Environmental Change, 6: 115-123.

Oldfield, F. and Dearing, J.A., 2003: The role of human activities in past environmental change. In: Alverson, K., et al. (Eds), Paleoclimate, Global Change and the Future, IGBP Synthesis Book Series, Springer Verlag, 143-162. Organic Carbon, Salinity, Toxic Pollution, Sediment infilling, and effects of Climate Change.

\title{
Integrated History and future Of People on Earth (IHOPE)
}

\author{
Kathy HibBard ${ }^{1}$ and Robert Costanza ${ }^{2}$ \\ 'National Center for Atmospheric Research, USA; kathyh@ucar.edu \\ Gund Institute for Ecological Economics, University of Vermont, USA; Robert.Costanza@uvm.edu
}

\section{Background and Goals}

Human history has traditionally been cast in terms of the rise and fall of great civilizations, wars, and specific human achievements. This history excludes the important ecological and climate contexts that shaped and mediated these events (Fig. 1). Human history and Earth System science have traditionally been developed independently, with little interaction among the academic communities. Separate methods of describing these histories have, therefore, been developed, and there have been few attempts to integrate these histories and information across these fields of study. Recent recognition that current Earth System changes are strongly associated with the changes in the coupled human-environment system make the integration of human history and Earth System history an important step in understanding the factors leading to global change and in developing strategies for the future.

The goal of the Integrated History and future Of People on Earth (IHOPE) project
(Costanza et al., 2007a) is to understand the interactions of the environmental and human processes over the past several ten to hundred millennia to determine how human and biophysical changes have contributed to Earth System dynamics. In order to reach this goal, our objective is to produce an integrated history of Earth System dynamics, technologies, human and land use systems and many additional variables from new and existing data sources in a spatially and temporally consistent framework.

Human-environment systems are intimately linked in ways that we are only beginning to appreciate (van der Leeuw, 1998; Redman, 1999; Steffen et al., 2004; Diamond, 2005; Kirch, 2005). To achieve the ambitious goals of IHOPE there are multiple scientific challenges that must be met. In order to fully understand the history of the Earth it is necessary to integrate the different perspectives, theories, tools, and knowledge of multiple disciplines across the full spectrum of social and natural sciences and the humanities.
Three major long-term goals have been identified for the IHOPE project:

1. Map the integrated record of biophysical and human system change since time of human settlement, e.g., Australian history might cover up to the last 60,000 years, and in southern Europe, the last 20,000 years would capture initial colonization since the Last Glacial Maximum (LGM).

2. Understand and evaluate the connections and dynamics of humans-in-environment systems' models against an integrated history, e.g., how well do various models of the relationships between climate, agriculture, technology, disease, and other variables explain the historical patterns of human settlement, population, energy use, and biogeochemistry?

3. Project options for the future of humanity and Earth System dynamics based on integrated models and histories. 


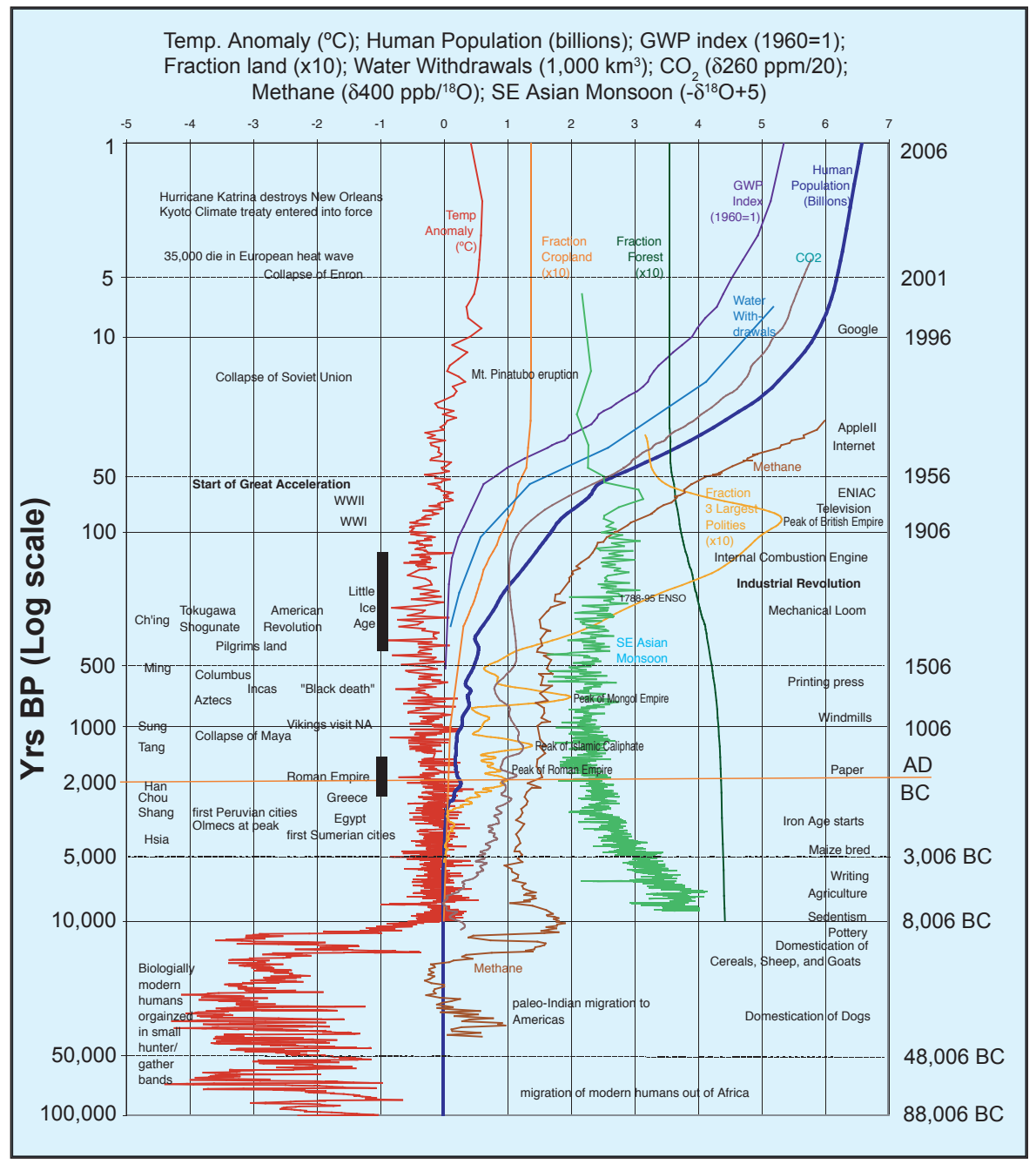

Figure 1: Selected indicators of environmental and human history from $100 \mathrm{kyr}$ BP to present.

\section{An Initial Timeline}

An initial and partial timeline (Fig. 1) of environmental and human history demonstrates the scope and challenges for IHOPE (Costanza et al., in review). In the graph, time is plotted on the vertical axis on a log scale running from $100 \mathrm{kyr}$ BP to present. Technological events are listed on the right and cultural/political events are listed on the left. Human population fluctuated globally at around 1 million until the advent of agriculture, after which it began to increase exponentially (with some declines, such as during the Black Death in Europe) to a current population of over 6 billion. Gross World Product (GWP) followed with some lag as people tapped new energy sources such as wind and eventually fossil fuels. Atmospheric $\mathrm{CO}_{2}$ and $\mathrm{CH}_{4}$ closely track population, GWP and energy use for the last 150 years. The start of the "Great Acceleration" after WWII can be clearly seen in the GWP, population, and water withdrawal plots. While this depiction of past events is integrative and suggestive of major patterns and developments in the human-environment interaction, it plots only coincidence, not causation.
The development of an integrated history began at an IHOPE-Dahlem conference in 2005 with the goal of firstly identifying how humans have responded to, and impacted, their environment over past millennial, centennial and decadal scales, and secondly the futures of the human-environment system (Costanza et al., 2007a). The overall conclusion from IHOPE-Dahlem was that human societies respond to environmental signals (e.g. climate) through multiple pathways including coping, adaptation, collapse or failure, migration, and creative invention through discovery. Extreme drought, for instance, has likely triggered both social collapse and ingenious management of water. Following the IHOPE-Dahlem, an international symposium was held in Japan on Sustainability of Islands and ResourceRecycling Societies. Discussions included the sustainability and failure of past and present Mayan, Monsoon Asia, Pacific Island and Atlantic Island civilizations in addition to future models for sustainability and technologies for resource recycling. In January 2006, an IHOPE workshop was held in Stockholm to draft a research plan.
This research plan has been reviewed by PAGES and approved for co-sponsorship by the International Human Dimensions Programme (IHDP; www.ihdp.org). In February 2007, a working group convened at Arizona State University to develop a flexible data system for IHOPE. Work is currently in progress towards implementation of an IHOPE Integrated Research System (IRIS) with the Archaeomedes dataset from Sander vander Leeuw and co-workers. An IHOPE-Asia workshop in northwestern Japan was held in March 2007 and included over 100 participants from Asia (e.g. Japan, China, Cambodia, Indonesia, Thailand) as well as Europe and the USA.

The IHOPE activity is led by Robert Costanza, Lisa Graumlich, Sander van der Leeuw, Will Steffen, John Dearing, Carole Crumley and Kathy Hibbard.

\section{References}

Costanza, R., Graumlich, L.J., and Steffen, W. (Eds) 2007: Sustainability or Collapse? An Integrated History and Future of People on Earth. Dahlem Workshop Report 96. MIT Press, Cambridge, MA.

Diamond, J. 2005: Collapse: How Societies Choose to Fail or Succeed. New York, Viking.

Kirch, P.V., 2005: Archeology and Global Change: the Holocene Record Annual Review Environmental Resources, 30: 409-440.

Redman, C. L., 1999: Human impacts on the Ancient Environment, Tucson, University of Arizona Press.

Steffen, W., Sanderson, A., Tyson, P., Jäger, J., Matson, P., Moore III, B. Oldfield, F., Richardson, K., Schellnhuber, H-J., Turner II, B.L., and Wasson, R., 2004: Global Change and the Earth System: A Planet Under Pressure, IGBP Global Change Series, Springer-Verlag, Berlin, Heidelburg, New York: 336.

For full references please consult:

www.pages-igbp.org/products/newsletters/ref2007_1.html 